\title{
A PCR-Based Assay to Detect Rhynchosporium secalis in Barley Seed
}

\author{
H. K. Lee and J. P. Tewari, Department of Agricultural, Food, and Nutritional Science, University of Alberta, \\ Edmonton, AB T6G 2P5, Canada; and T. K. Turkington, Agriculture and Agri-Food Canada, Lacombe Research \\ Center, $6000 \mathrm{C}$ and E Trail, Lacombe, AB T4L 1W1, Canada
}

\begin{abstract}
Lee, H. K., Tewari, J. P., and Turkington, T. K. 2001. A PCR-based assay to detect Rhynchosporium secalis in barley seed. Plant Dis. 85:220-225.

A polymerase chain reaction (PCR)-based diagnostic assay was developed to detect Rhynchosporium secalis, the barley scald fungus, in barley seed. Species-specific primers were designed based on sequence data of a region consisting of the 5.8S RNA gene and internal transcribed spacers 1 and 2 of $R$. secalis. The sequenced regions showed $100 \%$ homology between the two R. secalis isolates and $93 \%$ homology between $R$. secalis and $R$. orthosporum. Five sets of synthesized oligonucleotide primers were tested for their specificity using 29 isolates of $R$. secalis of diverse geographic origins and from different barley cultivars. In addition, DNA extracts from 22 species of microbes either taxonomically related to or from the same niche as $R$. secalis were tested as negative controls. Among five sets of primers, a primer set, RS8 and RS9, was selected for use in detecting $R$. secalis because it amplified a 264-bp fragment from the DNA of all $R$. secalis isolates but not the DNA from other species used for validation of the specificity of this primer set. This primer set was also used to detect $R$. secalis in barley seed and successfully amplified the predicted size of the DNA fragment in the infected material. PCR detection of as little as 1 to $10 \mathrm{pg}$ of $R$. secalis DNA was possible. The method described here requires 1 day for completion, compared to 10 days required for the cultural method.
\end{abstract}

Leaf scald, caused by the fungus Rhynchosporium secalis (Oudem.) J. J. Davis, is an important disease of barley in many parts of the world. Canada is now the third-largest barley producer and scald of barley is one of the major diseases in the cooler, moister regions of the prairies (29). In Alberta, which has just under one-half of the Canadian barley acreage, yield losses of up to $30 \%$ and average yield losses of $2.4 \%$ due to leaf scald have been reported (2,23). Although barley stubble is the primary habitat for survival of the dormant mycelium of $R$. secalis, the pathogen is also seedborne $(3,8,11,14,26)$. Seedborne inoculum may be responsible for early epidemics under favorable conditions, for introduction of $R$. secalis into new areas, and also for dispersal of new races.

Visual inspection of external symptoms on seeds has been the method employed for diagnosing seedborne infection of $R$. secalis. However, scald symptoms can be confused with other diseases, and the symptomless seeds will be ignored by this method (14). A recently developed cultural method based on isolation of the scald pathogen is another choice of a diagnostic method (16). The cultural method is supe-

Corresponding author: J. P. Tewari

E-mail: jtewari@afns.ualberta.ca

Accepted for publication 24 October 2000.

Publication no. D-2000-1206-02R

(c) 2001 The American Phytopathological Society rior to conventional visual disease assessment because it also gives information about the viability of inoculum of the pathogen. However, this method is not practical for routine seed testing because it is laborious and time consuming. The introduction of disease into areas previously unsown with barley, or which have been substantially free from the disease, may be due to symptomless seeds as well as seeds with visible infection (14). Therefore, it is desirable to develop a reliable, rapid, and sensitive diagnostic method for detecting seedborne infection by this pathogen.

In the last decade, molecular approaches have revolutionized the detection, identification, and quantification of phytopathogenic microbes. The polymerase chain reaction (PCR) assay is one approach that allows detection of extremely small quantities of specific DNA in complex environments. The utility of PCR as a specific and sensitive assay for identification of plant pathogens is well documented (9). The PCR is highly sensitive and reproducible for amplification of diagnostic molecular markers, and could easily be used for identification and detection if species-specific primers are available. Although molecular methods have been widely used for detection, identification, and phylogenetic study of the various phytopathogenic fungi, attempts to use molecular approaches for detecting seed infection have gained attention only recently $(5,10,24,25,27,28,33)$.

Ribosomal genes and the spacers between them provide attractive targets for detection and phylogenetic studies, because more than 50 copies may be present per genome. This suggests a high sensitivity of detection. The ribosomal genes and spacers between them possess conserved sequences as well as variable sequences, so they can be easily amplified and sequenced with universal primers based on their conserved sequences (31). Nuclear rDNA consists of the small and large subunits, 5.8S, and the internal transcribed spacer (ITS) region in fungi, and each sequence is variable at the family, genus, or species level. The ITS regions between the $18 \mathrm{~S}$ and $28 \mathrm{~S}$ rDNA subunits, which are nontranscribed regions, have considerably greater sequence variation between species. For these reasons, ITS regions have been widely used for developing species-specific probes or for designing primers for detection of pathogens of interest $(1,7,12,13,20,21,23)$.

The objective of the present study was to develop a PCR-based detection method for $R$. secalis using pathogen-specific primers and evaluate its use for diagnosis of scald infection in barley seed. A preliminary report on this work has been published (17).

\section{MATERIALS AND METHODS}

Sources of isolates and cultural maintenance. $R$. secalis isolates from different locations in Canada and different barley cultivars were chosen for this study (Table $1)$. Cultures of $R$. secalis were revived from stock cultures stored in $10 \%$ aqueous glycerol in liquid nitrogen at $-196^{\circ} \mathrm{C}$ and maintained on lima bean agar (LBA) plates at $16^{\circ} \mathrm{C}$. All other cultures used in this study (Table 1) were maintained on potato dextrose agar (PDA) plates at $20^{\circ} \mathrm{C}$.

DNA extraction. Total fungal genomic DNA was extracted from cultures growing on sterile cellophane discs (Biorad \#1650963) overlaid on LBA or PDA. Fungal mycelium was scraped off the cellophane disc and transferred to $1.5-\mathrm{ml}$ microfuge tubes for DNA extraction according to the method of Lecellier et al. (15) with some modifications. The DNA pellet was dissolved in $100 \mu \mathrm{l}$ of Tris-EDTA buffer, treated with RNase A $\left(100 \mu \mathrm{g} \mathrm{ml}{ }^{-1}\right)$ at $37^{\circ} \mathrm{C}$ for $30 \mathrm{~min}$, extracted once with chloroform-isoamylalcohol, and precipitated with isopropanol. The resulting pellet was dissolved in Tris-EDTA buffer. Total bacterial genomic DNA was extracted from cultures growing on PDA plates according to the method of Li and DeBoer (19). Total 
DNA from barley seed was extracted using the hexadecyl trimethylammonium bromide (CTAB) method described by Weising et al. (30). Barley seeds were surface sterilized with $70 \%$ ethanol for $30 \mathrm{~s}$ and washed several times with sterilized distilled water. Seeds were ground to a fine powder for $15 \mathrm{~min}$ using a mixer mill grinder (Brinkmann, Rexdale, Ontario, Canada). Ground seed powder (0.1 g) was suspended in the extraction buffer $(1.4 \mathrm{M}$ $\mathrm{NaCl}, 20 \mathrm{mM}$ EDTA, $100 \mathrm{mM}$ Tris- $\mathrm{HCl}$, $\mathrm{pH} 8.0$, containing $2 \%$ CTAB and $0.2 \% \beta$ mercaptoethanol). The suspension was incubated at $65^{\circ} \mathrm{C}$ for $30 \mathrm{~min}$ and extracted twice with chloroform/isoamylalcohol (24:1, $\mathrm{vol} / \mathrm{vol})$. The aqueous phase was incubated at $37^{\circ} \mathrm{C}$ for $1 \mathrm{~h}$ with RNase (final concentration of $100 \mu \mathrm{g} \mathrm{ml}^{-1}$ ). The DNA was recovered by precipitation with an equal volume of isopropanol, washed with $70 \%$ ethanol containing $10 \mathrm{mM}$ ammonium acetate, and dissolved in $100 \mu \mathrm{l}$ of TrisEDTA buffer. DNA stocks were further diluted 10 - to 100 -fold in sterilized distilled water and the equivalent of $0.1 \mathrm{mg}$ dry weight in $3 \mu$ l was used for PCR reactions. The concentration of DNA stocks was estimated using Gene Quant, RNA/DNA calculator (Pharmacia LKB Biochrom Ltd., Cambridge, England) at $260 \mathrm{~nm}$.

PCR amplification. The universal primers ITS1 and ITS4, derived from conserved sequences of $18 \mathrm{~S}$ and $28 \mathrm{~S}$ rDNA, were used to amplify the ITS region of $R$. secalis rDNA as described by White et al. (31). PCR amplification was carried out in $25 \mu$ of the reaction mixture containing $1 \times$ PCR buffer (20 mM Tris-HCl, pH 8.4; 50 $\mathrm{mM} \mathrm{KCl} ; 1.5 \mathrm{mM} \mathrm{MgCl}_{2}$ ), $0.2 \mathrm{mM}$ each of dATP, dCTP, dGTP, and dTTP, $250 \mathrm{nM}$

Table 1. Isolates and results of the polymerase chain reaction (PCR) assays using RS8 and RS9 primers

\begin{tabular}{|c|c|c|c|c|}
\hline Species & Isolates $^{\text {a }}$ & Host $^{\text {b }}$ & Origin & PCR product ${ }^{c}$ \\
\hline Rhynchosporium secalis & RL 001 & Falcon & Edmonton, $\mathrm{AB}$ & + \\
\hline Rhynchosporium secalis & RL 006 & CDC Guardian & Edmonton, AB & + \\
\hline Rhynchosporium secalis & RL 009 & Abee & Edmonton, $\mathrm{AB}$ & + \\
\hline Rhynchosporium secalis & RL 013 & Harrington & Edmonton, AB & + \\
\hline Rhynchosporium secalis & RL 018 & Tukwa & Edmonton, AB & + \\
\hline Rhynchosporium secalis & RL 024 & Duke & Edmonton, AB & + \\
\hline Rhynchosporium secalis & RL 027 & AC Stacey & Edmonton, $\mathrm{AB}$ & + \\
\hline Rhynchosporium secalis & RL 030 & Leduc & Edmonton, $\mathrm{AB}$ & + \\
\hline Rhynchosporium secalis & RL 038 & AC Lacombe & Edmonton, AB & + \\
\hline Rhynchosporium secalis & RL 042 & Jackson & Edmonton, AB & + \\
\hline Rhynchosporium secalis & RL 044 & Manley & Edmonton, AB & + \\
\hline Rhynchosporium secalis & RL 048 & Galt & Edmonton, AB & + \\
\hline Rhynchosporium secalis & RL 053 & Klages & Edmonton, AB & + \\
\hline Rhynchosporium secalis & RL 057 & AWP1602 & Edmonton, AB & + \\
\hline Rhynchosporium secalis & RL 059 & B1215 & Edmonton, AB & + \\
\hline Rhynchosporium secalis & RL 083 & Tukwa & Bowden, AB & + \\
\hline Rhynchosporium secalis & RL 087 & Harrington & Bowden, AB & + \\
\hline Rhynchosporium secalis & RL 092 & Unknown & Red Deer, AB & + \\
\hline Rhynchosporium secalis & RL $099(1824)^{d}$ & Unknown & Pilot Mound, MN & + \\
\hline Rhynchosporium secalis & RL $100(1395)^{d}$ & Winter barley & Guelph, ON & + \\
\hline Rhynchosporium secalis & RL $101(1826)^{d}$ & Leduc & Sylvan Lake, AB & + \\
\hline Rhynchosporium secalis & RL $102(1493)^{d}$ & Unknown & Tisdale, SK & + \\
\hline Rhynchosporium secalis & RL $105(1389)^{d}$ & Winter barley & Arnell Station, ON & + \\
\hline Rhynchosporium secalis & RL $106(1874)^{d}$ & Unknown & Medstead, SK & + \\
\hline Rhynchosporium secalis & RL 107 & Brome grass & Michener Park, AB & + \\
\hline Rhynchosporium secalis & RS 006 & Manley & Westlock gro site, $\mathrm{AB}$ & + \\
\hline Rhynchosporium secalis & RS 014 & Stander & Westlock gro site, $\mathrm{AB}$ & + \\
\hline Rhynchosporium secalis & RS 015 & CDC Earl & Westlock gro site, $\mathrm{AB}$ & + \\
\hline Rhynchosporium secalis & RS 020 & Harrington & Westlock gro site, $\mathrm{AB}$ & + \\
\hline Acremonium sp. & Co\#1 & Harrington & Westlock gro site, $\mathrm{AB}$ & - \\
\hline Microdochium sp. & $\mathrm{Co \# 2}$ & Harrington & Westlock gro site, $\mathrm{AB}$ & - \\
\hline Penicillium chrysogenum & $\mathrm{Co \# 3}$ & Harrington & Westlock gro site, $\mathrm{AB}$ & - \\
\hline Cladosporium sp. & $\mathrm{Co \# 4}$ & Harrington & Westlock gro site, $\mathrm{AB}$ & - \\
\hline Alternaria alternata & Co\#5 & Harrington & Westlock gro site, $\mathrm{AB}$ & - \\
\hline Mycelia sterilia & Co\#6 & Harrington & Westlock gro site, $\mathrm{AB}$ & - \\
\hline Ulocladium sp. & $\mathrm{Co \# 7}$ & Harrington & Westlock gro site, $\mathrm{AB}$ & - \\
\hline Pyrenophora graminea & $720(\text { on })^{\mathrm{d}}$ & Unknown & Unknown & - \\
\hline Cochliobolus sativus & $718(\text { on })^{\mathrm{d}}$ & Unknown & Unknown & - \\
\hline Pyrenophora teres & $858 \mathrm{WRS}^{\mathrm{d}}$ & Unknown & Unknown & - \\
\hline Stagonospora nodorum & $1899 \mathrm{WRS}^{\mathrm{d}}$ & Unknown & Unknown & - \\
\hline Fusarium graminearum (Gibberella zeae) & $\mathrm{G}-1^{\mathrm{d}}$ & Unknown & Unknown & - \\
\hline Collectotrichum graminicola & $1725 \mathrm{WRS}^{\mathrm{d}}$ & Unknown & Unknown & - \\
\hline Sporobolomyces sp. & Co\#8 & Harrington & Westlock gro site, $\mathrm{AB}$ & - \\
\hline Gerlarchia oryzae & ATCC 32154 & Rice & Allen Parish Farm, Louisiana & - \\
\hline Rhynchosporium orthosporum & CBS 698.79 & Orchard grass & Unknown & - \\
\hline Ustilago nuda & $\ldots$ & Harrington & Westlock gro site, $\mathrm{AB}$ & - \\
\hline Pseudomonas syringae pv. atrofaciens & $\# 3894^{\mathrm{d}}$ & Unknown & Unknown & - \\
\hline Xanthomonas campestris pv. translucens & $\# 4790^{\mathrm{d}}$ & Unknown & Unknown & - \\
\hline Unidentified bacterial isolate & Co\#9 & Harrington & Westlock gro site, $\mathrm{AB}$ & - \\
\hline Unidentified bacterial isolate & Co\#10 & Harrington & Westlock gro site, $\mathrm{AB}$ & - \\
\hline Unidentified bacterial isolate & Co\#11 & Harrington & Westlock gro site, $\mathrm{AB}$ & - \\
\hline
\end{tabular}

a Isolated from leaf lesions (RL) or from infected seed (RS). ATCC = American Type Culture Collection, Rockville, MD. CBS = Centraalbureau voor Schimmelcultures, Baarn, The Netherlands. Co = contaminants isolated from barley seeds. Some of these were identified with the help of Identification Service, CABI Bioscience, Surry, UK.

b Hosts are barley cultivars, except for brome grass, rice, and orchard grass.

c Presence (+) or absence (-) of 264-bp DNA fragment after PCR amplification.

${ }^{\mathrm{d}}$ Isolates provided by Dr. Andy Tekauz, Agriculture and Agri-Food Canada, Winnipeg, Manitoba. 
of each forward and reverse primer, 0.6 units Taq DNA polymerase (GIBCOBRL), and $30 \mathrm{ng}$ genomic DNA. PCR amplification was carried out in a GeneAmp PCR system 2400 (Perkin-Elmer, Norwalk, CT) with the following amplification conditions: initial denaturation at $94^{\circ} \mathrm{C}$ for $3 \mathrm{~min}, 25$ cycles of denaturation at $94^{\circ} \mathrm{C}$ for $1 \mathrm{~min}$, annealing at $55^{\circ} \mathrm{C}$ for $1 \mathrm{~min}$, and extension at $72^{\circ} \mathrm{C}$ for $2 \mathrm{~min}$, with the final extension at $72^{\circ} \mathrm{C}$ for 10 min. A 10- $\mu$ l aliquot of the PCR amplified products was separated on a $1.5 \%$ agarose gel in Tris-borate-EDTA buffer at $100 \mathrm{~V}$ for $1 \mathrm{~h}$. The gel was stained with ethidium bromide for $15 \mathrm{~min}$ and the PCR products were viewed using a UV transilluminator.

DNA sequencing and primer design. Single DNA fragments amplified by the PCR with the primers ITS1 and ITS4 from two isolates of $R$. secalis from cvs. Harrington (RS020) and Manley (RS006) and one isolate of $R$. orthosporum were excised from the agarose gel and purified with the Agarose Gel DNA Extraction Kit (Boehringer, Mannheim, Germany). The purified fragments were sequenced at the DNA Services Laboratory, Department of Biological Science, University of Alberta. Sequence data were compared with the aid of the computer program GenejockyII (P. L. Taylor, Cambridge, UK) and potential primers were designed using the program Amplify 1.2 (Bill Engels, Madison, WI). Nine primer sequences within the ITS regions 1 and 2 were selected based on the sequence differences found between $R$. secalis and $R$. orthosporum and an average $\mathrm{G}-\mathrm{C}$ content ranging from 40 to $55 \%$ (Table 2). These are referred to as primers RS1, RS2, RS3, RS4, RS5, RS6, RS7, sized at the DNA Services Laboratory, Department of Biological Science, University of Alberta.

Test of primer specificity. Five primer sets were tested for the amplification of the predicted-size fragments and for specificity to $R$. secalis at different annealing temperatures $\left(55,60,65\right.$, and $\left.70^{\circ} \mathrm{C}\right)$ using the $R$. secalis isolate $\mathrm{RS} 020$ and $R$. orthosporum. The same five primer sets also were used to amplify DNA from the isolates of $R$. secalis from a range of geoRS8, and RS9. The primers were synthe-

graphic origins and from different barley cultivars. DNA from isolates of contaminants isolated from barley seeds, taxonomically related species, and microbes from the same ecological niche as $R$. secalis also were used to validate primer specificity (Table 1).

Detection of $\boldsymbol{R}$. secalis in barley seed. Primers were also tested for the detection of $R$. secalis from barley seed. Seeds of the cv. Harrington, 100 with typical scald symptoms and 100 healthy looking, were sorted out and ground separately into powder as described previously. Various amounts of $R$. secalis-infected seed powder were serially mixed with uninfected seed powder to determine the minimum level of detection using species-specific primers. A total of $0.1 \mathrm{~g}$ of ground seed powder was used for each sample. The artificially infested ground seed powder had 100, 80, 60, $40,20,10,8,6,4,2,1$, and $0 \%$ infestation with the $R$. secalis-infected seed powder. Control amplifications of DNA from seeds of the $R$. secalis-resistant cultivar Seebe and PCR reaction mixture lacking DNA were included as negative controls. Five replicates were used for each level of artificial $R$. secalis infestation in the ground seed powder and PCR amplification. Forty PCR cycles were used to amplify DNA from seed samples.

\section{RESULTS}

Sequence of the ITS region of $R$. secalis. Amplification of $R$. secalis and $R$. orthosporum DNA with ITS1 and ITS4 universal primers resulted in 627- and 625bp single fragments, respectively. The sequences of ITS regions containing $5.8 \mathrm{~S}$ rDNA, ITS1, and ITS2 in the two isolates of $R$. secalis from different cultivars were identical. Sequence alignment of $R$. secalis with $R$. orthosporum revealed overall $93 \%$ homology, $86 \%$ homology in the ITS1, and $95 \%$ homology in the ITS2 regions. However, the sequences of the $3^{\prime}$ end of the $18 \mathrm{~S}$ and $5.8 \mathrm{~S}$ genes, and the $5^{\prime}$ end of the $28 \mathrm{~S}$ gene were identical between $R$. secalis and R. orthosporum (Fig. 1).

Primer selection and specificity to $R$. secalis. Based on sequence differences found within the ITS regions of two species, five sets of primers (A, B, C, D, and

Table 2. Sequences of primer sets derived from the internal transcribed spacer region of Rhynchosporium secalis

\begin{tabular}{lclc}
\hline Set & $\begin{array}{c}\text { Primer } \\
\text { designation }\end{array}$ & \multicolumn{1}{c}{ Sequence (match at) } & $\begin{array}{c}\text { Expected fragment } \\
\text { size (bp) }\end{array}$ \\
\hline A & RS1 & AAGAAGCCTGGTTCAGACCTCC (115) & 371 \\
& RS3 & ACCGCCACTGATTTTAGGGG (486) & 339 \\
B & RS2 & AAACTACCTCTGTTGCTTTGCAGG(147) & \\
& RS3 & ACCGCCACTGATTTTAGGGG (486) & 456 \\
C & RS4 & ATAGAGCAATGAACAGTCGG (31) & 419 \\
& RS5 & CACCGCCACTGATTTTAGGG (487) & \\
D & RS6 & CTCCACCCTTGAATAAACTACC(133) & 264 \\
& RS7 & GTTGTTGGCAAGTAGACCAGCC (552) & \\
E & RS8 & TTGTTTTTAGTGATGTCTGAG (226) & \\
& RS9 & AGGCACCGCCACTGATTTTAGGG (490) & \\
\hline
\end{tabular}

E) were selected and tested for their specificity in detecting $R$. secalis (Table 2). All primer sets amplified the expected size of single fragments from all isolates of $R$. secalis tested when the annealing temperature was $55^{\circ} \mathrm{C}$. However, except for primer set E (RS8 and RS9), sets A, B, C, and $\mathrm{D}$ amplified a similarly sized single fragment from the DNA extracts of $R$. orthosporum, showing different intensities. These fragments could be eliminated by increasing the annealing temperature to 65 and $70^{\circ} \mathrm{C}$ for the primer sets $\mathrm{A}$ and $\mathrm{B}$ and the primer sets $\mathrm{C}$ and $\mathrm{D}$, respectively. The primer set E amplified a 264-bp fragment from all DNA extracts of $R$. secalis isolates, but not from those of other species considered taxonomically and ecologically most closely related to $R$. secalis. Therefore, primer set $\mathrm{E}$ was used for further experiments to detect $R$. secalis in barley seeds.

Sensitivity of PCR detection assay. Amplification reactions were conducted with decreasing amounts of the genomic DNA of $R$. secalis to determine the minimum amount of input DNA required to produce a detectable product using the primer sets A and E. These primer pairs were able to direct the amplification of the target DNA sequence from as little as $1 \mathrm{pg}$ of DNA for set A and $10 \mathrm{pg}$ of DNA for set E (Fig. 2).

PCR detection of $R$. secalis DNA in extracts from barley seeds. The primer set $\mathrm{E}$ was used to detect $R$. secalis-DNA in extracts of seed of cv. Harrington (Fig. 3). PCR products from initial DNA extracts were not detected by electrophoresis. However, when the DNA extracts were diluted from 10- to 100-fold with sterilized distilled water, distinct bands for the pathogen-DNA amplification products were observed. DNA extracts were diluted 30 -fold with sterilized distilled water in subsequent experiments. The results of five replicates using samples of ground $R$. secalis-infected seed powder that were serially mixed with ground uninfected seed powder are summarized in Table 3. In the five independent experiments, the detection levels at 0,1 , and $2 \%$ of infestation with the infected seed powder were variable. The negative controls (DNA extract from seeds of the resistant cultivar, Seebe, and the reaction mixture without DNA) did not reveal any amplification, whereas the positive control ( $R$. secalis DNA) showed strong positive PCR product amplification (Fig. 3).

\section{DISCUSSION}

In this study, a PCR-based diagnostic assay was developed to detect $R$. secalis in barley seed using pathogen-specific primers derived from the ITS region of rDNA of $R$. secalis. Nuclear ribosomal DNA sequences have been an attractive source for designing species-specific primers for detection or differentiation of the pathogen 
185 rRNA

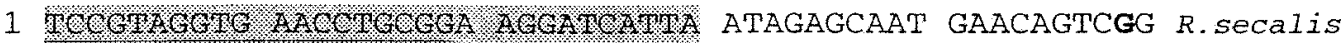

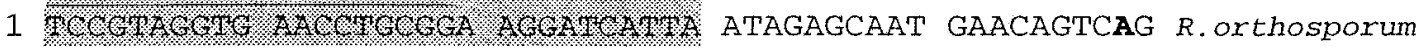
ITS $1 \rightarrow$

51 CGCCCCAGGA GAAATCCTGG GGGCTACCCT ACTTCGGTGG GGTTTAGAGA $R$. secalis

51 CGCCCCAGGA GCGATCCTGG GGGCTACCCT -CTTCGG-AG GGTTTAGAGA $R$ orthosporum

101 CGTCAGGCCG CTCGAAGAAG CCTGGTTCAG ACCTCCACCC TTGAATAAAC R.secalis

99 CGTCGGGCCC TTCGGGGATA CTCGGTTCAG ACCTCCACCC TTGAATACAT R.orthosporum

151 TACCTCTGTT GCTTTGGCAG GCCGCCTAGC GCCAGCGGCT TCGGCTGCTG R. secalis

149 TACCTTTGTT GCTTTGGCAG GACGCCTCGT GCCAGCGGCT TCGGCTGTTG R.orthosporum

RS $8 \rightarrow$

201 AGTGCCTGCC AGAGGACCAC AACTCTTGTT TTTAGTGATG TCTGAGTACT $R$. secalis

199 AGTGCCTGCC AGAGGACCAC AACTCGTGAA ACATATGAAG TCTGAGTACT R. orthosporum

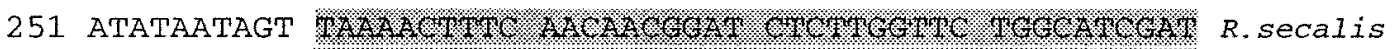

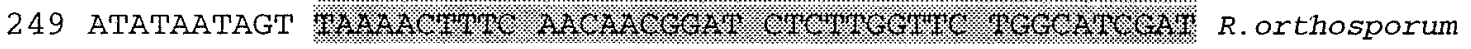

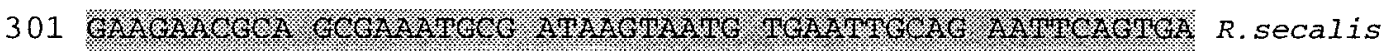

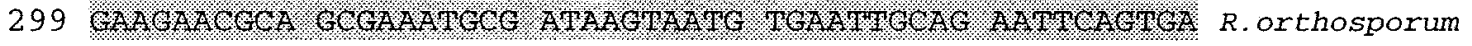

$$
\text { 5. 8.S TRNA }
$$

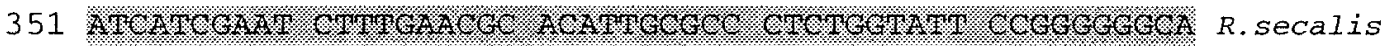

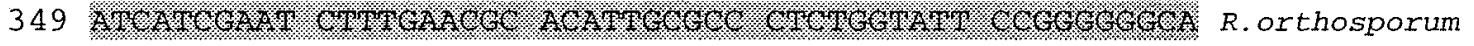

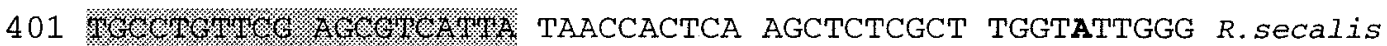

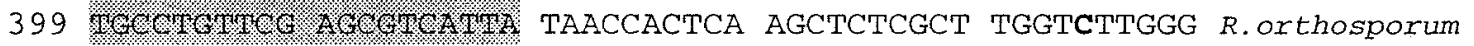

$$
\leftarrow \text { RS } 9
$$

451 GTTCGCGTCC TCGCGGCCCC TAAAATCAGT GGCGGTGCCT GTCGGCTCTA R. secalis

449 GTTCGCGTCC TCGCGGCTCC TAAAATCAGT GGCGGTGCCG GTCGGCTCTA R.orthosporum

501 CGCGTAGTAA TACTCCTCGC GATTGAGTCC GGCTGGTCTA CTTGCCAACA R. secalis

499 CGCGTAGTAA TACTCCTCGC GATTGAGTCC GGTCGGTCTA CTTGCCAACA R.orthosporum

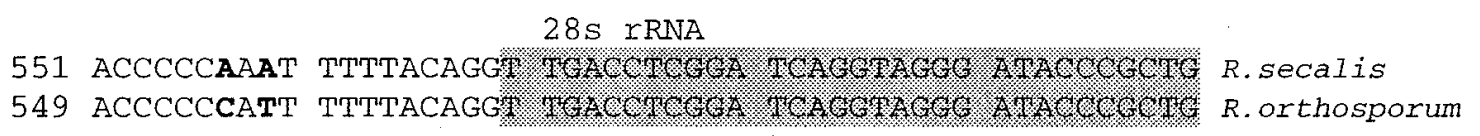

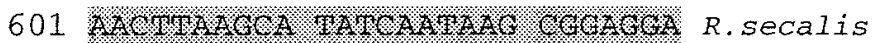

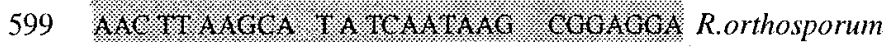

$\leftarrow \operatorname{ITS} 4$

Fig. 1. Sequence comparison of the internal transcribed spacer (ITS) region and 5.8S rRNA gene from Rhynchosporium secalis (RS20) and R. orthosporum. The sequences typed in bold letters indicate differences in the ITS regions of the two species. 
of interest, because they are generally highly conserved within the species, yet variable among species $(1,7,12,13,20,21$, $22,27,32)$. This study revealed that DNA sequences of the two isolates of $R$. secalis from cvs. Harrington and Manley were identical over a 627-bp stretch from the $3^{\prime}$ end of the 18S rRNA gene to the $5^{\prime}$ end of the $28 \mathrm{~S}$ rRNA gene. The complete homology of the ITS regions of the two isolates is consistent with the view that the ITS region is conserved within the species (30). However, there was $93 \%$ homology in the ITS regions between $R$. secalis and $R$. orthosporum. Besides $R$. secalis, $R$. orthosporum and $R$. alismatis are two other known species belonging to the genus Rhynchosporium $(3,4,6)$. Whereas $R$. alismatis is known to attack some weed species of the family Alismataceae, $R$. orthosporum, the causal agent of the leaf scald disease of orchard grass and some other grasses, has a broad host range, including some common grass species that are also known to be attacked by $R$. secalis $(3,4,6)$. The pathogen, $R$. orthosporum, is also known to produce symptoms identical to those of $R$. secalis and has similar characteristics, except for the production of uniformly cylindrical conidia $(3,6)$. Therefore, in this study, $R$. orthosporum was used to compare its ITS sequence with that of $R$. secalis. Sequence divergence found in the ITS1 (95\% identity) and ITS2 ( $86 \%$ identity) regions between the two species suggested the potential value of the ITS sequence as a molecular marker for $R$. secalis. Five sets of primers, constructed from the divergent sequences within the ITS1 and ITS2 regions of $R$. secalis, produced fragments of expected size from the DNA extract of $R$. secalis. However, the primer sets $\mathrm{A}, \mathrm{B}, \mathrm{C}$, and $\mathrm{D}$, but not primer set $\mathrm{E}$, failed to differentiate $R$. secalis from $R$. orthosporum at $55^{\circ} \mathrm{C}$, the

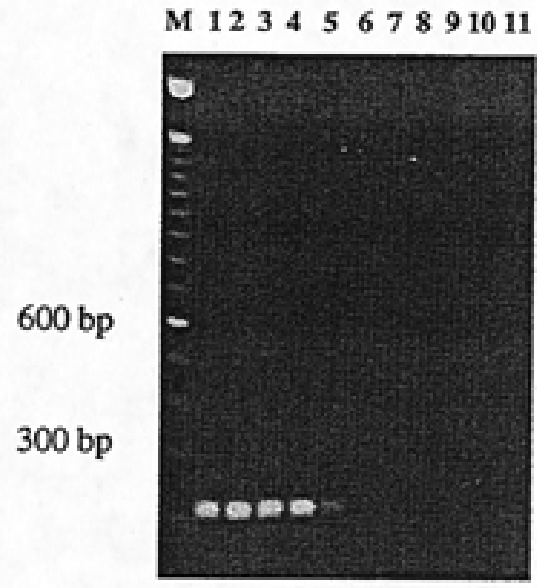

Fig. 2. Determination of the minimum amount of input DNA of Rhynchosporium secalis using primer set E. Lanes: $M=100-b p$ DNA marker, $1=30 \mathrm{ng} / \mu \mathrm{l}, 2=10 \mathrm{ng} / \mu \mathrm{l}, 3=1 \mathrm{ng} / \mu \mathrm{l}, 4=100$ $\mathrm{pg} / \mu \mathrm{l}, 5=10 \mathrm{pg} / \mu \mathrm{l}, 6=1 \mathrm{pg} / \mu \mathrm{l}, 7=100 \mathrm{fg} / \mu \mathrm{l}, 8$ $=10 \mathrm{fg} / \mu \mathrm{l}, 9=1 \mathrm{fg} / \mu \mathrm{l}, 10=0 ; 11, R$. orthosporum $(30 \mathrm{ng} / \mu \mathrm{l})$. initial annealing temperature. The reduced sensitivity of these primers could be explained by the fact that primer sets A, B, $\mathrm{C}$, and $\mathrm{D}$ were derived from the less divergent sequences of the ITS region, which included one or several sequence differences between the two species. Increasing the annealing temperature for those primer sets allowed differentiation between $R$. secalis and $R$. orthosporum. However, $R$. orthosporum is not known to attack barley; therefore, those primer sets also can be used to detect $R$. secalis in barley seed without concerns of cross reactivity with $R$. orthosporum. Although all primer sets appeared to be species specific after optimizing the PCR cycle, primer set E was selected for this study due to its high specificity. All primer sets produced detectable fragments from as little as 1 to 10 pg of $R$. secalis DNA.

Scald symptoms are distributed over the lemmas, paleas, awns, glumes, and rachises $(8,14,26)$. Lemma and palea lesions have been the basis for visual disease assessment (14). Therefore, in sampling for PCR-based detection, seeds bearing no symptoms on the lemma and palea and seeds with visible symptoms were separately sorted and tested. PCR amplification of fungal DNA in a crude DNA extract from $0.1 \mathrm{~g}$ of seed samples allowed for the detection of a presumably small biomass of $R$. secalis. Effects of inhibitors of the PCR reaction commonly found in the DNA extracts from plant materials were overcome by diluting the $R$. secalis DNA from 10- to 100-fold with sterilized distilled water. The PCR amplification revealed the presence of $R$. secalis in the series of $R$. secalis-infested powdered seed samples. Even though a difference in the band intensity for each level of $R$. secalis-infested samples was found, sample-to-sample variation was observed in different replications of samples prepared for the lower levels of $R$. secalis infestation $(<2 \%)$. The variability in PCR results of the five independent experiments may be due to variations in inoculum loads in the samples. In replications 1 and 4, the DNA extracts from seed powder that had $0 \%$ infestation with $R$. secalis produced a faint band, whereas the negative control samples without any DNA

\section{$\begin{array}{llllllllllllllll}M & 1 & 2 & 3 & 4 & 5 & 6 & 7 & 8 & 9 & 10 & 11 & 12 & 13 & 14 & 15\end{array}$}

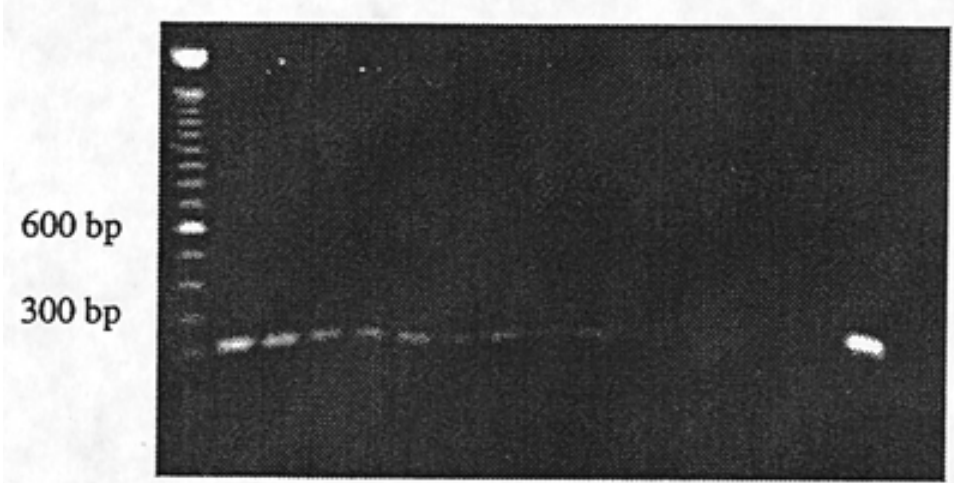

Fig. 3. Amplification of Rhynchosporium secalis DNA at different levels of scald infection of barley seeds. Lanes: $\mathrm{M}=100$-bp DNA marker, $1=100 \%, 2=80 \%, 3=60 \%, 4=40 \%, 5=20 \%, 6=10 \%, 7$ $=8 \%, 8=6 \%, 9=4 \%, 10=2 \%, 11=1 \%, 12=0 \%, 13=$ DNA extract from resistant barley cultivar Seebe, $14=$ negative control (polymerase chain reaction mixture lacking in DNA), $15=$ positive control ( $R$. secalis DNA).

Table 3. Results of detection of Rhynchosporium secalis in preparations of infected and uninfected barley seed using polymerase chain reaction (PCR)

\begin{tabular}{lcccccc}
\hline & \multicolumn{5}{c}{ Detection of $\boldsymbol{R}$ secalis by PCR amplification $^{\mathbf{a}}$} & \\
\cline { 2 - 6 } Seed infected (\%) & Rep. 1 & Rep. 2 & Rep. 3 & Rep. 4 & Rep. 5 & Detection $(\%)^{\mathbf{b}}$ \\
\hline 100 & + & + & + & + & + & 100 \\
80 & + & + & + & + & + & 100 \\
60 & + & + & + & + & + & 100 \\
40 & + & + & + & + & + & 100 \\
20 & + & + & + & + & + & 100 \\
10 & + & + & + & + & + & 100 \\
8 & + & + & + & + & + & 100 \\
6 & + & + & + & + & + & 100 \\
4 & + & + & + & + & + & 100 \\
2 & + & - & + & + & + & 80 \\
1 & + & - & - & + & - & 40 \\
0 & + & - & - & + & - & 40 \\
\hline
\end{tabular}

a Presence (+) or absence (-) of $R$. secalis-specific band after PCR amplification.

b Percent detection level by PCR. 
did not produce any bands. This indicated that the results were not a false positive by PCR contamination. The fact that $R$. secalis was detected in the asymptomatic sample may be due to sensitivity of the PCR assay. Symptomless infection of barley seeds by $R$. secalis was reported by Kay and Owen (14) and Lee et al. (18).

Although there has been much interest in the use of PCR assays for detection and characterization of phytopathogenic microbes in general, PCR for the detection of seedborne pathogens has received little attention $(5,27,28,33)$. In this study, attempts to construct $R$. secalis-specific primers to detect the pathogen from barley seed, which was conventionally assayed by visual disease assessment, were successful. In comparison to those PCR-based assays used for detection of other seedborne pathogens which require long incubation periods for completion of the assay $(27,28)$, the methodology described here only takes about one working day from DNA extraction to PCR detection, without a pathogen-enrichment period. In addition, the method described is more sensitive and less laborious compared to the cultural method, which takes about 10 days for incubation (16). The PCR-based diagnostic assay described here for testing barley seed health provides several benefits over conventional methods for $R$. secalis. However, in practical terms, the assay needs to be more quantitative. Further research is being carried out to make the assay quantitative. Furthermore, the assay is based on the presence or absence of a diagnostic molecular marker; therefore, it would be useful for epidemiological studies of the pathogen.

\section{LITERATURE CITED}

1. Beck, J. J., and Ligon, J. M. 1995. Polymerase chain reaction assay for the detection of Stagonospora nodorum and Septoria tritici in wheat. Phytopathology 85:319-324.

2. Buchannon, K. W., and Wallace, H. A. H. 1962. Note on the effect of leaf diseases on yield, bushel weight, and thousand-kernel weight of Parkland barley. Can. J. Plant Sci. 42:534-536.

3. Caldwell, R. M. 1937. Rhynchosporium scald of barley, rye, and other grasses. J. Agric. Res. 55:175-198.

4. Cother, E. J., and Gilbert, R. L. 1994. Pathogenicity of Rhynchosporium alismatis and its potential as a mycoherbicide on several weed species in the Alismataceae. Aust. Exp. Agric. 34:1039-1042.

5. Doohan, F. M., Parry, D. W., Jenkinson, P., and Nicholson, P. 1998. The use of speciesspecific PCR-based assays to analyze Fusarium ear blight of wheat. Plant Pathol. 47:197-205.

6. Ferrandez, J. P., and Welty, R. E. 1991. Histopathology of orchardgrass infected by Rhynchosporium orthosporum. Mycologia 83:774778.

7. Goodwin, P. H., Hsiang, T., Xue, B. G., and Liu, H. W. 1995. Differentiation of Gaeumannomyces graminis from other turf-grass fungi by amplification with primers from ribosomal internal transcribed spacers. Plant Pathol. 44:384-391.

8. Habgood, R. M. 1971. The transmission of Rhynchosporium secalis by infected barley seed. Plant Pathol. 20:80-81.

9. Henson, J. M., and French, R. 1993. The polymerase chain reaction and plant disease diagnosis. Annu. Rev. Phytopathol. 31:81109.

10. Huff, D. R., Bunting, T. E., and Plumley, K. A. 1994. Use of random amplified polymorphic DNA markers for the detection of genetic variation in Magnaporthe poae. Phytopathology 84:1312-1316.

11. Jackson, L. F., and Webster, R. K. 1976. Seed and grasses as possible sources of Rhynchosporium secalis for barley in California. Plant Dis. Rep. 60:233-236.

12. Johanson, A., and Jeger, M. J. 1993. Use of PCR for detection of Mycosphaerella fijiensis and M. musicola, the causal agents of Sigatoka leaf spots in banana and plantain. Mycol. Res. 97:670-674.

13. Kageyama, K., Ohyama, A., and Hyakumachi, M. 1997. Detection of Pythium ultimum using polymerase chain reaction with species-specific primers. Plant Dis. 81:1155-1160.

14. Kay, J. G., and Owen, H. 1973. Transmission of Rhynchosporium secalis on barley grain. Trans. Br. Mycol. Soc. 60:405-411.

15. Lecellier, G., and Silar, P. 1994. Rapid methods for nucleic acids extraction from petri dish-grown mycelia. Curr. Genet. 25:122-123.

16. Lee, H. K., Tewari, J. P., and Turkington, T. K. 1999. Histopathology and isolation of Rhynchosporium secalis from infected barley seed. Seed Sci. \& Technol. 27:477-482.

17. Lee, H. K., Tewari, J. P., and Turkington, T. K. 1999. Use of PCR-based assay to detect Rhynchosporium secalis in infected barley seed.(Abstr.) Phytopathology 89:S44.

18. Lee, H. K., Tewari, J. P., and Turkington, T. K. 1999. Symptomless infection of barley seed by Rhynchosporium secalis. (Abstr.) Annu. Meet. Plant Pathol. Soc. Alberta, Jasper, Alberta.

19. Li, X., and De Boer, S. H. 1995 Selection of polymerase chain reaction primers from an RNA intergenic spacer region for specific de- tection of Clavibacter michiganensis subsp. sepedonicus. Phytopathology 85:837-842.

20. Lovic, B. R., Martyn, R. D., and Miller, M. E. 1995. Sequence analysis of the ITS regions of rDNA in Monosporascus spp. to evaluate its potential for PCR-mediated detection. Phytopathology 85:655-661.

21. Lovic, B. R., Valadez, V. A., Martyn, R. D., and Miller, M. E. 1995. Detection and identification of Monosporascus spp. with genusspecific PCR primers and nonradioactive hybridization probes. Plant Dis. 79:1169-1175

22. Mazzola, M., Wong, D. T., and Cook, R. J. 1996. Virulence of Rhizoctonia oryzae AG-8 on wheat and detection of $R$. oryzae in plant tissue by PCR. Phytopathology 86:354-360.

23. McLelland, M. B. 1989. Barley production in Alberta. Agdex 114/20-I. Alberta Agriculture, Food and Rural Development, Lacombe, Alberta, Canada.

24. Parry, D. W., and Nicholson, P. 1996. Development of a PCR assay to detect Fusarium poae in wheat. Plant Pathol. 45:383-391.

25. Reeves, J. C. 1995. Nucleic acid techniques in testing for seedborne diseases. Pages 127-149 in: New Diagnostics in Crop Science. J. H. Skerritt and R. Appels, eds. CAB International, Wallingford, Oxon, UK.

26. Skoropad, W. P. 1959. Seed and seedling infection of barley by Rhynchosporium secalis. Phytopathology 49:623-626.

27. Smith, O. P., Peterson, G. L., Beck, R. J. Schaad, N. W., and Bonde, M. R. 1996. Development of a PCR-based method for identification of Tilletia indica, casual agent of karnal bunt of wheat. Phytopathology 86:115122.

28. Taylor, J. L. 1993. A simple, sensitive, and rapid method for detecting seed contaminated with highly virulent Leptosphaeria maculans. Appl. Environ. Microbiol. 59:3681-3685.

29. Tekauz, A. 1991. Pathogenic variability in Rhynchosporium secalis on barley in Canada. Can. J. Plant Pathol. 13:298-304.

30. Weising, K., Nybom, H., Wolff, K., and Meyer, W.1995. DNA isolation and purification. Pages 51-54 in: DNA Fingerprinting in Plants and Fungi. CRC Press, Boca Raton, FL.

31. White, T. J., Bruns, T., Lee, S., and Taylor, J. 1990. Amplification and direct sequencing of fungal ribosomal RNA genes for phylogenetics. Pages 315-322 in: PCR Protocols: A Guide to Methods and Applications. M. A. Innis, D. H. Gelfand, J. J. Sninsky, and T. J. White, eds. Academic Press, New York.

32. Willitis, D. A., and Sherwood, J. E. 1999. Polymerase chain reaction detection of Ustilago hordei in leaves of susceptible and resistant barley varieties. Phytopathology 89:212-217.

33. Yao, C. L., Frederiksen, R. A., and Magill, C. W. 1990. Seed transmission of sorghum downy mildew: detection by DNA hybridization. Seed Sci. \& Technol. 18:201-207. 